\section{News About Sections}

Kay Sterling

American Political Science Association

\section{New Sections}

The new Section on Political Communication was established to foster the study of political communication within the discipline of political science and to facilitate scholarly exchange among APSA members who have an interest in this growing research area. More specifically, the Section seeks to provide a forum for research on the mass media and their effects on the public, political institutions and processes, telecommunications policy, and new media technologies, as well as research on the process of communicating and understanding about politics.

Kathy Frankovich is head of the nominating committee to present a slate of officers. Her address and phone number are: CBS News, Election \& Survey Unit, 524 West 57th Street, New York, NY 10019. (212) 975-66/5. Marion Just. Wellesley College, is the section's acting chairman of the constitution and bylaws committee. She may be contacted at (617) 235-0320, extension 2206.

Further information on this new section may be found in the list of section officers presented in this issue.

The new Section on History and Politics was organized to bring together political scientists interested in historical issues and problems. This is a diverse group in which almost every traditional disciplinary subfield is represented, and there is a broad array of approaches as well. For some, historical studies expand the number of cases of interest; for others, historical puzzles are appropriate foils for demonstrating the explanatory power of favorite theories; still others bring new evidence to bear on familiar stories.

An executive committee representing the diversity in subject and approach of students of history and politics include: Lisa Anderson (Columbia University). Peter Hall (Harvard), Michael Smith (Uni- versity of Virginia), and $H$. Douglas Price (Harvard), Chair. Contact persons for this new section may be found in the section officers listing in this issue.

The Comparative Politics Section encourages APSA members and others to submit paper and panel proposals to John Freeman, the 1990 Annual Meeting Program Organizer. Write or call him at Department of Political Science, 14/4 Social Sciences, University of Minnesota, Minneapolis, MN 55455, (612) 6246081.

\section{Committee on Status of Blacks Honors Summer Institute}

The Committee on the Status of Blacks recognized the achievement of those associated with the Summer Institute in Political Science for Black Students at its annual Annual Meeting reception. The Summer Institute, established in 1986, was designed to encourage black students to pursue academic careers in political science. For the past four years, the Institute has been jointly hosted by Southern University and Louisiana State University. The Institute has been sponsored by APSA with support from the Ford Foundation.

As the Institute concluded its final year at Southern University and LSU, the Committee on the Status of Blacks honored Institute co-directors Peter Zwick of LSU and Jewel Prestage of Southern University. Others associated with the Summer Institute whose significant contributions were also recognized included: Ronald $E$. Weber of LSU, Melanie N. Jackson of Southern University; Gloria J. Braxton of Southern University, Michael Combs of University of Nebraska, Earl Picard of Prairie View A \& M University, Cheryl Grimes of Southern University, and Eva Fields of Southern University.

Mitchell Rice, chair of the Committee on the Status of Blacks, noting the extraordinary contribution of the Summer Institute organizers, also affirmed the Association's intention to carry on the Summer Institute in a new location. Beginning in 